\title{
THE FAMILY THELYPTERIDACEAE IN EUROPE
}

\author{
R. E. HOLTTUM
}

\begin{abstract}
SUMMARY: Thelypteridaceae are mainly tropical ferns, the total number of species is about one thousand. The five European species represent five different groups, each of which has recently been accorded generic status. Thelypteris palustris Schott (including three varieties) extends throughout north temperate regions, with a closely allied species south of the equator; chromosome numker $\mathrm{n}=35$. Phaegopteris connectilis (Michx) Watt (triploid with base number 30) and Oreopteris limbosperma (All.) Holub $(n=34)$ are members of small genera confined to north temperate regions. Stegnogramma pozoi (Lag.) K. Iwats. $(n=36)$ represents a genus of 12-15 species, mainly in Africa and Asia, with one in Mexico. Christella dentata (Forsk.) Brownsey \& Jermy is a wide-ranging and variable tetraploid species of a pantropic genus (c. $60 \mathrm{spp}$ ) the centre of distribution of wich appears to be Burma-Assam (base number 36).

The genus Cyclosurus (s. str.) comprises a small pantropic group of species with grow (like Thelypteris) in open permanently swampy ground; I belive Cyclosorus and Thelypteris to be closely related genera. Stegnogramma is related to Sphaerostephanos which (in arrangement of Holttum) is the most diversified genus in the Old World with c. $140 \mathrm{spp}$. in Malesia. Christella is probably also related to Sphaerostephanos though less nearly than Stegnogramma.
\end{abstract}

RESUMEN: Las Thelypteridaceae son helechos principalmente tropicales, comprende aproximadamente mil especies. Las cinco especies europeas representan cinco grupos diferentes cada uno de los cuales ha recibido recientemente un estatus genérico. Thelypteris palustris Schott (incluyendo tres variedades) se extiende por las regiones templadas del norte, con un conjunto de especies próximas al sur del ecuador; el número cromosómico es $n=35$. Phegopteris connectilis (Michx) Watt (triploide con número básico 30) y Oreopteris limbosperma (All.) Holub $(n=34)$, son miembros de pequeños géneros confinados a las regiones templadas del norte.

Stegnogramma pozoi (Lag.) K. Iwats. $(n=36)$ representa un género de 12-15 especies principalmente de Africa y Asia con una en Méjico. Christe lla dentata (Forsk.) Brownsey \& Jermy es una variable especie tetraploide de amplia distribución cuyo género pantropical (cerca de 60 especies) parece tener su centro de distribución en Burma-Assam (número básico 36 ).

El género Cyclosorus (s. str.) comprende un pequeño grupo de especies pantropicales que viven en llanuras permanentemente pantanosas. Creemos que Cyclosorus y Thelypteris son géneros muy emparentados. Stegnogramma está relacionado con Sphaerostephanos, el cual (en la ordenación de Holctum) es el género más diversificado en el viejo mundo con cerca de 140 especies en Malasia Christella esta tambien relacionada,probablemente, con Sphaerostephanos aunque su proximidad es menor que la mantenida con Stegnogramma. 


\section{R.E. HOLTTUM}

This family comprises almost one thousand species, distributed mainly in the wetter parts of the tropics. In mainland Europe there are five species, and of these two occur only in Spain (one of them also in Crete). In New Zealand there are four species, one of which occurs also in Spain. By contrast, there are about 440 species in Malesia, which I have been studying intensively during the past twelve years, following the work of R.C. Ching on the species of China and India. Simultaneously Dr. A.R. Smith in California has been studying the species of the New World, and our work has met in a consideration fo the species of Africa which have relations both to west and east of that continent. The result of all this study has been the recognition of a new set of natural groups of species which I have ranked as genera. These differ from the generic concepts in Copeland's Genera Filicum (1947) where the two principal genera (Lastrea and Cyclosorus) are both composite and some natural groups of species overlap both "genera". The European species belong to five distinct genera each of which belongs to a different group of genera in my scheme, the main part of which is set forth in Table I. The principal group omitted is confined to Malesia and the Pacific; there are also some temperate North American and Asian species the position of which is not yet clear, a tropical American group (Steiropteris) and a small genus in Asia which has trilete spores.

In the 19th centry the species in this family, rarely well described, were not distinguished from Dryopteris and other genera having sori of a similar shape. The most important character distinguishing thelypteroid ferns was first noticed by Carl Christensen in his study of the tropical American species which he had included in Dryopteris in his Index Filicum (1905); this caracter is the universal presence of unicellular acicular hairs on the upper surface of all axes of fronds. He rightly claimed that species sharing this character had also other characters in common which marked them as a distinct taxonomic group. R.C. Ching later pointed out that another common character is the presence of two vascular strands at the base of the stipe, the two uniting upwards to form a single strand U-shaped in section (Flora Europaea has the erroneous statement that the stipe in this family has 5-7 vascular strands, which is true of Dryopteris). A combination of these two kinds of character, which are not functionally connected, is sufficient to mark a fern as a member of the family Thelypteridaceae, with only one exception, namely Hypodematium (limestone plants of tropical and subtropical Asia) which has very different scales and perhaps is most nearly allied to Athyrium.

Other less distinctive characters also mark the family. The scales which cover very young fronds at the crozier stage have unicellular outgrowths, usually acicular but sometimes spherical, from the surfaces of many cells, in most cases not only marginal ones; scales of true Dryopteris and other genera with similar sori have no superficial hairs, and projections on their margins are of a different character. The large proportion of tropical thelypteroid species which have anastomosing veins all show a sinus-membrane with an excurrent vein passing to the base of it. The difference between Thelypteridaceae and Dryopteris, and also the diversity of the former, is shown by their chromosome numbers, which have a range from 27 to 36 in Thelypteridaceae whereas Dryopteris has 41 (some reiated genera have 40 ). A character of many species in the family, but not well shown by those in Europe, is the presence of swollen aerophores at the bases of pinnae. Another frequent character is the presence of unicellular glands, either on the surfaces of fronds or on sporangia, or both; such glands are of several different kinds, characteristic 
of different genera or groups of genera; three kinds are shown by European species. Generic distributions are interesting. Two European genera (Phegopteris and Oreopteris) have a north temperate distribution, one (Thelypteris) is worldwide, the other two (Christella and Stegnogramma) mainly in the tropics of the Old World.

\begin{tabular}{|c|c|c|c|c|}
\hline $\begin{array}{l}\text { Distinctive characters } \\
\text { of groups }\end{array}$ & $\begin{array}{l}n^{\circ} \text { of } \\
\text { spp. }\end{array}$ & genera & $\begin{array}{c}\text { chrom. } \\
\text { nº }\end{array}$ & distrib. \\
\hline $\begin{array}{l}\text { 1. Group of Phegopteris: } \\
\text { costa not grooved on upper surface } \\
\text { veins not reaching margin } \\
\text { fronds mostly bipinnate }\end{array}$ & $\begin{array}{l}3 \\
20 \\
10 \\
12\end{array}$ & $\begin{array}{l}\text { PHEGOPTERIS } \\
\text { Pseudophegopteris } \\
\text { Macrothelypteris } \\
\text { Metathelypteris }\end{array}$ & $\begin{array}{l}30 \\
31 \\
31 \\
35\end{array}$ & $\begin{array}{l}\text { N. Temp. } \\
\text { O.W. Trop. } \\
\text { O.W. Trop. } \\
\text { O.W. Trop. }\end{array}$ \\
\hline $\begin{array}{l}\text { 2. Group. of Amauropelta: } \\
\text { caudex usually erect } \\
\text { glands resinous }\end{array}$ & $\begin{array}{r}200 \\
50 \\
3\end{array}$ & $\begin{array}{l}\text { Amauropelta } \\
\text { Coryphopteris } \\
\text { OREOPTERIS }\end{array}$ & $\begin{array}{l}29 \\
33 \\
34\end{array}$ & $\begin{array}{l}\text { N.W. Trop. } \\
\text { Malesia } \\
\text { Temp. disj. }\end{array}$ \\
\hline $\begin{array}{l}\text { 3. Group of Thelypteris: } \\
\text { caudex creeping } \\
\text { large red glands } \\
\text { scales on costae }\end{array}$ & $\begin{array}{r}3 \\
3 \\
18\end{array}$ & $\begin{array}{l}\text { THELYPTERIS } \\
\text { Cyclosorus } \\
\text { Mesophlebion }\end{array}$ & $\begin{array}{l}35 \\
36 \\
36\end{array}$ & $\begin{array}{l}\text { Temp. N \& S } \\
\text { Pantrop. } \\
\text { Malesia }\end{array}$ \\
\hline $\begin{array}{l}\text { 4. Group of Goniopteris: } \\
\text { many asastomosing veins } \\
\text { lower pinnae not reduced } \\
\text { glands (if present) spherical }\end{array}$ & $\begin{array}{l}70 \\
10 \\
60\end{array}$ & $\begin{array}{l}\text { Goniopteris } \\
\text { Meniscium } \\
\text { Pronephrium }\end{array}$ & $\begin{array}{l}36 \\
36 \\
36\end{array}$ & $\begin{array}{l}\text { N.W. Trop. } \\
\text { N.W. Trop. } \\
\text { O.W.Trop. }\end{array}$ \\
\hline $\begin{array}{l}\text { 5. Group of Sphaerostephanos: } \\
\text { lower pinnae usually much reduced } \\
\text { some anastomosis of veins } \\
\text { glands (if present) spherical }\end{array}$ & $\begin{array}{r}160 \\
18 \\
80\end{array}$ & $\begin{array}{l}\text { Sphaerostephanos } \\
\text { STEGNOGRAMMA } \\
\text { Pneumatopteris }\end{array}$ & $\begin{array}{l}36 \\
36 \\
36\end{array}$ & $\begin{array}{l}\text { O.W. Trop. } \\
\text { O.W. Trop. } \\
\text { O.W. Trop. }\end{array}$ \\
\hline $\begin{array}{l}\text { 6. Group of Christella } \\
\text { few lower pinnae gradually reduced } \\
\text { some anastomosis of veins }\end{array}$ & $\begin{array}{l}60 \\
10\end{array}$ & $\begin{array}{l}\text { CHRISTELLA } \\
\text { Amphineuron }\end{array}$ & $\begin{array}{l}36 \\
36\end{array}$ & $\begin{array}{l}\text { Pentrop. } \\
\text { o.w.trop. }\end{array}$ \\
\hline
\end{tabular}

Table 1.- Thelypteridaceae: Principal groups of genera

\section{THE PHEGOPTERIS GROUP OF GENERA}

These genera have two characters the regular association of which was first observed by R.C. Ching: the costae of pinnae are prominent, not grooved, on the upper surface, and the veins do not reach the margin. In the two principal genera (Pseudophegopteris and Macrothelypteris) the fronds are large and fully bipinnate; both have the chromosome number 31 but they are distinct in spores and scales, also in adaptations to different habitats. Metathelypteris comprises a few species on mountains in S.E. Asia (two are tetraploids and widely distributed), one in Madagascar and Fernando Po, and two which are each known only from a single collection in West Afri$\mathrm{ca}$. Metathelypteris has the same chromosome number $(\mathrm{n}=35)$ as Thelypteris, but the two genera are certainly very distinct and not closely related. Phegopteris itself comprises three. P. connectilis is an apogamous triploid which occurs almost throughout north temperate regions and is also known as a sexual diploid in Japan; it has received various different specific epithets, as shown below. P hexagonaptera is a closely allied diploid in North America. The third species, P. decursivepinnata, occurs only in China, Korea and Japan and has fronds of a very different shape, elongate and narrowed 
to both ends; in Japan both diploid and tetraploid forms have been found but there is no report on the morphological distinctions between them.

Linnaeus gave the name Polypodium phegopteris to the European species, and it remained in Polypodium in the systems of Swartz and Hooker. In 1852 Fée established a genus Phegopteris for terrestrial ferns with exindusiate round sori and fronds not articulate to the rhizome as are, those of true Polypodium. Fée still placed his genus next to Polypodium. It contained a considerable diversity of species, but was adopted by other authors, including Beddome whose Indian ferns under that name include species now placed in Dryopteris, Ctenits, Gymnocarpium, Hypolepis and Monachosorum. Mettenius (1856) also adopted the genus (Fil. Hort. Lips. pp. 14, 81) but he transferred it from Polypodiaceae to Aspidiaceae and subdivided it critically. Diels (1899) finally united indusiate and exindusiate ferns under the name Nephrodium, which was changed to Dryopteris in Christensen's Index filicum of 1905. Christensen was very conscious that his Dryopteris represented a complex mixture, but he refused to make a formal subdivion into separate genera until he had learned enough to distinguish them clearly. Copeland included Phegopteris in Lastrea (Genera Filicum, 1947) which comprised all Thelypteridaceae which have free veins, an unnatural mixture. The first author to recogize Phegopteris in its present restricted sense was Ching.

The distinctive characters of the genus are: semicircular wings along the rachis connecting the pinnae, the main veins in some of the wings arising directly from the rachis; scales on the rachis thin, transclucent with filiform apices, their margins bearing slender unicellular hairs, transitions from such scales to hairs present on the lower surface of costae of the pinnae; costae prominent on the upper surface, not grooved; veins not reaching the margin except some distal ones; sori near the apices of veins, exindusiate (or with very small indusia in P. decursivepinnata); spores have a complex raised irregular reticulum of fine meshes, much as in Macrothelypteris, very different from Pseudophegopteris.

Select synonymy of the European species:

Phegopteris connectilis (Michx) Watt, Canad. Nat. (1870) 29; Norton, Amer. Fern J., 57 (1967) 177; Holttum, Blumea 17 (1969) 10.

Basionym: Polypodium connectilis Michx, Fl. Bor. Amer., 2 (1803) 271.

Earliest name, with variants: Polypodium phegopteris Linn., Sp. P1. (1753) 1089.

Lastrea phegopteris Bory Dict. Class., 9 (1826) 233; Copel., Gen. Fil., (1947) 137.

Phegopteris polypodioides Fée Gen. Fil., (1852) 243; Manton, Probl. Cyt. and Evol. Pterid., (1950) 83; Ching, Acta Phytotax. Sinica, 8 (1963) 312; Hirabayashi, J. Jap. Bot., 44 (1969) 115.

Phegopteris vulgaris Mett., Fil. Hort. Lips., (1856) 83: Bedd., Handb. Ferns Brit. India, (1883) 290.

Thelypteris phegopteris Slosson in Rydb. Fl. Rocky Mts., (1917) 1043; Flora Europaea, 1 (1964) 14.

\section{THE OREOPTERIS GROUP OF GENERA}

The majority of ferns in all three genera have glands on the surface of their fronds; these glands are somewhat resinous and are 
different in each genus. Those in Oreopteris are spherical and free from the surface of the frond; the larger glands in Amauropelta are hemispherical, but there are varied smaller spherical ones; those in Coryphopteris are sessile, red-translucent, often collapsing when dried for the herbarium. Plants in all genera have an erect, or nearly erect, caudex, which in Amauropelta and Coryphopteris may reach $30 \mathrm{~cm}$. or more tall, giving the plants the aspect of miniature tree-ferns. Amauropelta is the largest genus, comprising about 200 species, the great majority in tropical America (A.R. Smith, American Fern Journ., 64: 83-95, 1974) with six species in Africa and adjacent Islands (Holttum, J. S. Afr. Bot., 40: 130-136, 1974) and three in the islands of the Pacific (Holttum, Allertonia, 1: 193-195, 1977). Coryphopteris comprises about fifty species, on the mountains of $\mathrm{Ma}-$ lesia, always near the crests of ridges, also on the mountains of a few islands in the Pacific as far as Tahiti (Holttum, Blumea, 23: $19-47,1976)$.

Oreopteris was first recognized as a distinct genus by Holub in 1969 (see synonymy below). The type species was first named Polypodium oreopteris in 1787. It was transferred by different subsequent authors to seven other genera, among them Lastrea Bory (1826). Bory included a mixture of diverse species in his genus and later authors who adopted the name used it in different senses. John Smith (Historia Filicum, 1875) cited Dryopteris filix-mas as type species. Beddome, in his work on Indian ferns, included in it species of Dryopteris, Ctenitis, Hypodematium, Lunathyrium and several thelypteroid genera. Christensen (Index Filicum: XXI, 1905) recognized that this confusion existed, and in his Monograph of Dryopteris (1913) ranked Lastrea as a subgenus to include the species now known as Amauropelta only. Copeland (1947) again recognized Lastrea as a genus, restricting it to thelypteroid ferns with free veins (but he also included Gymnocarpium, which is not thelypteroid) and cited L. oreopteris as type species. Ching (1963) in his new subdivision of the family, and Pichi Sermolli (1977) accepted the same type. But Holub (1969) pointed out that the original list of species in Lastrea included Polypodium thelypteris Linn. which is in effect the type species of Thelypteris. Therefore Lastrea is illegitimate, according to the present Code, for which reason Holub proposed the new generic name Oreopteris. In view of the great confusion of names under the genus Lastrea in the 19th century, I welcome this proposal for practical reasons. Holub adopted the original specific epithet as a generic name, so a new specific epithet has to be found for the type species; this was provided by Allioni when he published the name Polypodium limbospermum.

O. limbosperma is distributed throughout most of western Europe, southwards to the Pyrenees and northern Italy, eastwards to the Caspian Sea. . There is a closely related species ( $O$. quelpaertensis (Christ) Holub) in Japan, Korea, and from Kamchatka to Alaska and British Columbia; a third species in Sikkim (O. elewesii (Bak.) Holttum) is more distinct, with pinnae less deeply lobed, lower pinnae asymmetric, and smaller glands.

The generic characters are: caudex almost erect, with tufted fronds which are gradually narrowed to base and apex; stipe-scales thin with spherical outgrowths from some of the cells (no acicular hairs); pinnae deeply lobed; veins free, passing to the margin (except some lower ones); spherical glands present on all parts of the lower surface (few in O. quelpaertensis); sori supramedial, indusiate; glands-sometimes present on sporangia and on their stalks; pe- 
rispore consisting of well-developed irregular inter-connecting ridges; Chromosome number ( known for all species) 34 .

Select Synonymy for the European species:

Oreopteris limbosperma (All.) Holub, Folia Geobot. Phytotax., 4 (1969) 46. 49.

Basionym: Polypodium limbosperma All. Auct. Flor. Piedm., (1789)

Synonym: Thelypteris limbosperma (All.) H.P. Fuchs, Amer. Fern J., 48 (1958) 144; Flora Europea, 1 (1964) 13.

Earliest name and some of its variants: Polypodium oreopteris Ehrh. in Willd., Fl. Berol. Prodr. (1787) 292.

Lastrea oreopteris Bory, Dict. Class., 9 (1826) 233; Copel,. Gen. Fil., (1947) 136; Ching, Acta Phytotax. Sinica, 8 (1963) 298.

Nephrodium oreopteris Desv., Mem. Soc. Linn. Paris, 6 (1827) 257; Hook., Spec. Fil., 4 (1862) 89.

Phegopteris oreopteris Fée, Gen. Fil., (1852) 243.

Thelypteris oreopteris Slosson in Rybd. Fl. Rocky Mts (1917) 1043; Clapham, Tutin \& Warbrug, Fl. Brit. Isles, (1952) 46.

Illegitimate name: Polypodium montanum Vogler, Dissert., (1781) non Lam. 1773.

Nephrodium montanum Bak., Syn. Fil., (1867) 271; Diels in Engler \& Prantl, Nat. Pflanzenfam. I, Abt. 4 (1899) 173.

\section{THE THELYPTERIS GROUP OF GENERA}

The genus Thelypteris in the restricted sense here adopted consists of two or three North Temperate species and one southern species; the latter has a disjunct distribution in Africa south of tha Sahara, the mountains of southern India, North Sumatra and New Guinea, and the North Island of New Zealand. The southern species differs from the northern ones most conspicuously in the presence of rather large persistent almost circular scales on the lower surface of costae. All species grow only in permanently wet ground in rather exposed places. (Ching in 1963 included also Nephrodium griseum Bak., known only from one specimen from South India. In my judgement, this specimen represents an abnormal form of a species of Pseudocyclosorus).

The other genera in the group, Cyclosorus and Mesophlebion (also the monotypic genus Ampelopteris) agree in the presence of rather large red spherical glands at the ends of hairs on the stalks of sporangia and also sometimes on the lower surface of fronds. Such glands are absent in Thelypteris, but the costal scales of that genus end in a red glandular cell, seen on newly-developed scales. All genera agree in the presence of scales on the lower surface of costae; in most other members of the family such scales are rare (Phegopteris, Macrothelypteris and Coryphopteris also have them). Cyclosorus, of which the type species is C. gongylodes (Schkuhr) Link, consists of a pantropic complex (with one outlier in Algeria) which includes tetraploids in America, with one distinct species in Africa. Like Thelypteris they are all plants of open freshwater swamps; many Angiosperms of this habitat are also widely distributed. Mesophlebion, by contrast, consists entirely of forest plants in Malesia, one of which grows only in freshwater swamp-forest. A distinctive character of Mesophlebion is the position of the basal basiscopic vein of each group. All veins in each pinna-lobe in most members of the family arise as branches of the costules of the lobes, but in Mesophlebion the basal basiscopic one arises from the costa at some dis- 
tance from the base of its costule. This condition occurs to some extent also in Cyclosorus, where the basal veins anastomose to form an excurrent vein passing to the sinus-membrane between two adjacent lobes, as in most tropical members of the family.

The generic name Cyclosorus needs some explanation, as it has here a significance different from that adopted in Copeland's Genera Filicum (1947) and in Flora Europaea. Link published the name Cyclosorus for a single species Aspidium gongylodes Schkuhr, the type of which was a specimen from the Orinoco River belonging to the pantropic complex above mentioned (there were several earlier binomals which applied to other specimens of the same complex). C. gongylodes was included in Aspidium or Nephrodium by all later authors of the 19th century and in Dryopteris by Christensen in his Index Filicum (1905). When Christensen studied all tropical American species for his Monograph of Dryopteris (1913) he ranked Cyclosorus as a subgenus and included in it, besides the type species, a distinct natural group of species which have a different habit and a different pattern of pubescence, also (when present) a different type of glands on the stalks of sporangia. In Asia is a larger group of species which are clearly allied to these other species placed in subg. Cyclosorus by Christensen, for which reason Ching (1938) adopted the generic name Cyclosorus for them, and to them he added other species of Asia which are not closely related. All these species have anastomosing veins, and Ching separated them by this character from those which earlier (1936) he had placed in Thelypteris. Copeland accepted Ching's arrangement and included in Cyclosorus a much larger and more diverse group of species from Malesia. I adopted this system for the species of the Malay Peninsula in my book on the ferns of that area (1955) but expressed doubts as to the naturalness of the generic concepts, noting that at least one species in Thelypteris was more nearly related to a species in Cyclosorus than to any other in its own genus. Copeland's scheme was also accepted for Flora Europaea (there was no effective alternative) and so one European species is there included in Cyclosorus as $C$. dentatus; this is further discussed below under the name Christella dentata and certainly belongs to a different group of genera.

The history of the name Thelypteris also needs comment. It was first published as a generic name by Schmidel in 1763, with a reference to Acrostichum thelypteris Linn. but no binomial in the new genus; it was accompanied by a long description and an excellent series of illustrations. Several authors (including Copeland) rejected the name as illegitimate, but it is now acepted and is conserved against Dryopteris Adanson, as there is some doubt as to which was published first. It was ignored by most subsequent authors who transferred Acrostichum thelypteris Linn. to Aspidium, Lastrea, Nephrodium or Dryopteris. The name Thelypteris was revived by Nieuwland in 1910 to replace Dryopteris in the sense of Christensen's Index Filicum. Christensen objected to this (Ind. Fil. Suppl. III, 1934) on the grounds that the Dryopteris of 1905 needed to be subdivided into several genera, a process which should be delayed until more knowledge about the large number of species had been gained; he suggested that it should at most be limited to the species placed by him in Dryopteris subg. Lastrea of his monograph of 1913. The modern use of Thelypteris as a generic name began with Ching in 1936 for ferns of Asia, and was thus accepted by me for my book of 1955, with reservations (as above noted). The final restriction to its present content was made by Ching in 1963, and I have accepted it in my recent papers. 
The best taxonomic account of Thelypteris s. str. is by Fernald (1929) in which he recognized one species, T. palustris, divided into four varieties, It was not until 1967 that Morton published new information which established the status of two binomials which antedate T. palustris Schott (1834): Pteris confluens Thunb. 1800 for a South African specimen, and Nephrodium thelypteroides Michaux 1803 for a specimen from Canada. The former is the oldest valid binomial applying to any species of the genus, so that anyone who wishes to follow Fernald in recognizing only one species must use the name $T$. confluens (Thunb.) Morton. I prefer to regard the southern species, to which Thunberg's type belongs, as distinct. This leaves the problem that the next oldest name is Nephrodium thelypteroides Michaux. Those who regard the northern forms of Thelypteris as constituting one species distinct from the southern $T$. confluens must use the name Thelypteris thelypteroides Holub. In accepting this solution Holub recognized two varieties, var. thelypteroides in North America and var. glabra in Europe. Anyone who wishes to continue to use the name Thelypteris palustris for plants in Europe must recognize that they constitute a species different from the American ones. For practical purposes, and to avoid further confusion of names, I think that the latter course is preferable. A key to all species, including var. haleana Fernald (overlooked by Holub), based on Fernald's paper, is as follows.

\section{KEY TO THE SPECIES AND VARIETIES OF THELYPTERIS}

1. Scales on costae almost circular, large, persistent; indusium bearing acicular hairs and a few small glandular hairs .......... T. confluens

1. Scales on costae narrow to ovate, smaller, usually not persistent; indusia bearing either glandular or acicular hairs, not both kinds:

2. Indusia bearing glandular hairs only ... T. palustris

2. Indusia bearing acicular hairs ........ T. thelypteroides

3. Costal scales narrow, caducous; veins in middle fertile pinnae mostly simple.. var. thelypteroides

3. Costal scales ovate; veins in middle fer= tile pinnae mostly forked ......... var. haleana

Select synonymy of the species of Thelypteris:

Thelypteris palustris Schott, Gen. Fil. (1834) ad t. 10; Ching, Acta phytotax. Sinica 8 (1963) 298; Flora Europaea, 1 (1964) 13. Oldest name: Acrostichum thelypteris Linn., Sp. Pl. (1753) 1071. Synonym: Thelypteris thelypteroides (Michx) Holub, var. glabra Holub, Taxon, 21 (1972) 332.

Illegitimate name : Polypodium palustre Salisb. 1796, non Burm. fil. 1768 .

Thelypteris thelypteroides (Michx) Holub, Taxon, 21 (1972) 332.

Basionym: Nephrodium thelypteroides Michx, Fl.Bor.Amer. (1803) 267; Morton, Amer.Fern Journ., 57 (1967) 172 (type from Canada).

Synonyms: Lastrea thelypteris var. pubescens Lawson, Edinb. New Phil. Journ., n.s. 19 (1864) 277. Thelypteris palustris var. pubescens Fernald, Rhodora, 31 (1929) 34. muda).

Variety: var. haleana Fernald l.c. (S.E. United States and Ber- 
Thelypteris confluens (Thunb.) Morton, Contr. U.S.Nat. Herb., 38 (1967) 71; Schelpe, Fl. Zamb. Pterid. (1970) 190. (type from South Africa).

Basionym: Pteris confluens Thunb., Prodr. Fl. Cap. (1800) 171.

Synonyms: Aspidium thelypteris (Linn.) var. squamigerum Schlechtend., Adumb. Fil. Prom. B. Spei (1825) 23. Thelypteris palustris var. squamigera Weatherby, Contr. Gray Herb., 73 (1924) 40; Fernald l.c. 34. Thelypteris squamigera (err. typ. squamulosa) Ching. Acta Phytotax. Sinica 8 (1963) 298. (type from South Africa). Nephrodium squamulosum Hoo's fil, Fl. Nov. Zeyl., 2 (1854): 39. (type from New Zealand.

\section{THE SPHAEROSTEPHANOS GROUP OF GENERA}

Sphaerostephanos, in the revised concept proposed by me in 1971, is the largest genus of thelypteroid ferns in the Old World (about 170 species). A distirctive character of a majority of species is the presence of sessile spherical yellow glands which are firm and almost vitreous in appearance, not shrivelling when dried. These glands may be present on all parts of the plant including sporangia, but in some species occur only on indusia or sporangia, or they may be replaced by acicular hairs on sporangia. The sori are usually round and indusiate but may be elongate, as in the type species of the genus. The great majority of species have lobed pinnae with anastomosing basal veins, and abruptly much reduced lower pinnae, the true stipe being sometimes very short. Species of Pronephrium (in the Goniopteris group) have similar glands, where present, but their pinnae are shallowly lobed to entire and there are no reduced basal ones; it is a complex group, and perhaps part of it should be transferred to the Sphaerostephanos group.

The European species which I place in this group is named Thelypteris pozoi in Flora Europaea; it belongs to a group of species named Leptogramma by John Smith in 1841. In 1963 Iwatsuki united Leptogramma to Stegnogramma Bl., and as the latter is earlier it replaces Leptogramma for our species. The chief difference is that the type species Stegnogramma aspidioides has anastomosing veins. I accept Iwatsuki's arrangement. The characters of Stegnogramma as thus amended are: elongate exindusiate sori, the sporangia bearing slender acicular hairs; finely spinulose spores; pinnae more or less deeply lobed, the basal ones not or little reduced; veins free or anastomosing; stipe-scales bearing many short acicular hairs on their surface.

The genus Stegnogramma, as enlarged by Iwatsuki, has one species (originally named Gymnogramma pilosa Mart. \& Gal.) in Mexico and Guatemala, one in the Azores, Madeira and most of Africa, a few in mainland S.E. Asia and Japan and on the mountains of Malesia. The type species occurs in Java, Sumatra and Borneo. A few other tropical American species have a similar aspect but do not belong to the genus.

The European species has had several different names, based on specimens from Spain, Madeira and South Africa, all specific epithets having later been transferred to other genera. Plants in various parts of Africa vary in detail, and no good detailed comparative study of them has been made. Spanish plants are very much like those of Madeira which are tetraploid. Diploid plants in Ceylon represent at least a distinct variety, and a Japanese species is also diploid. I have seen no reports on the cytology of Spanish or African plants. 
Select Synonymy for the European species:

Stegnogramma pozoi (Lagasca) K. Iwats., Acta phytotax. Geobot . 19 (1963) 124.

Basionym and its variants: Hemionitis pozoi Lagasca, Nov. Gen. et Sp. (1816) 33. Thelypteris pozoi Morton, Bull. Soc. Bot. Fr. 106 (1959) 234; Schelpe, Fl. Zamb. Pterid. (1970) 199, with full synonymy. Leptogramma pozoi Heywood in Fedde Repert., 64 (1961) 19. (type from Spain).

Synonyms and their variants:

1. Polypodium tottum Willd., Spec. Pl., ed 4, 5 (1810) 201, non Thunb. 1800. Gymnogramma totta Schlechtend., Adumbr. Fil. Prom. B. Spei (1825) 15. Nephrodium tottum Diels in E. \& P. Nat. Pflanzenfam. I, Abt. 4 (1899) 170 (type from South Africa).

2. Acrostichum pilosiusculum Wikstr., K. Vet. Akad. Handl. 1825 (1826) 439. Leptogramma pilosiuscula Alston, Bol. Soc. Brot., Ser. 2A, 30 (1956) 17. (type from Madeira).

3. Polypodium africanum Desv., Mem. Soc. Linn. Paris, 6 (1827) 239. Dryopteris africana C. Chr. Ind. Fil. (1905) 250. Aspidium africanum Aschers. \& Graebn., Syn Mitteleur. Fl. ed. 2, 1 (1912) 28, 153. Lastrea africana Copel., Gen. Fil. (1947) 138. (type from South Africa).

4. Polypodium eliasii Sennen \& Pau, Bull. Soc. Geogr. Bot. Mans 20 (1910) 94. (type from Spain).

\section{THE CHRISTELLA GROUP OF GENERA}

The name Christella (which commemorates Hermann Christ) was proposed by Léveillé in his Flora of the Kweichow (Koui-tchéou) Province of China but rather vaguely defined and without citation of a type species. The species which he assigned to his genus are almost all thelypteroids and belong to four different genera of my scheme of 1971. In order to give a definite meaning to the name I had to select a type species. I selected Christella parasitica (Linn.) Lév. as type because this species belongs to the group which Christensen (wrongly, in my opinion) united to the type species of Cyclosorus (see above discussion under the Thelypteris group); this group pre-viously had no distinctive name. The single European species $C$. dentata is closely related to $C$. parasitica. The most distinctive character in the genus is the presence of unicellular elongate glands on the stalks of sporangia, in many species also on the lower suface of pinnae. The spores have a perispore of rather thick irregular ridges or tubercles. The fronds are almost always gradually reduced towards the base but the lowest pinnae are not minute as they often are in the Sphaerostephanos group. Both surfaces of pinnae, between the veins, often also indusia, bear more or less abundant acicular hairs. The majority of species have anastomosing veins but a few in the Western Pacific and a larger number in America and Africa have free veins. A. R. Smith has made a detailed study of the American species (see synonymy below).

The centre of distribution of the genus is Assam-Burma-W. China where there is the greatest diversity of species, most of which are forest plants and have been little studied in the living state. C. dentata is a tetraploid and as at present defined is very variable. It is adapted to open positions and has spread greatly as a result of the destruction of forest during the past century; it now occurs all over the tropics and subtropics of the Old World where sufficiently moist conditions occur, and (within the past fifty years) through human agency into the New World where now it is also widespread. 
The type of the species was collected by Forsskal in Arabia (Yemen) in 1773 .

C. dentata, C. parasitica and related species were the first group of tropical ferns investigated by Prof. I. Manton and her associates by modern cytogenetic experiments. Both $\mathrm{C}$. dentata and $\mathrm{C}$. parasitica are tetraploids, and Manton proved that they have one diploid parent in common. This diploid (named Cyclosorus repandulus in studies by Manton and associates) is also very widely distributed, but is not adapted to such exposed conditions as C. dentata. It has been named several times, from Timor, Mauritius, Guyana, Borneo, New Guinea and the Philippines; I believe that the oldest name is Aspidium hispidulum Decne from Timor.

The other genus which I have associated with Christella is Amphineuron, the type species of which (A. opulentum (Kaulf.) Holttum) is also very widely distributed and adapted to rather exposed situations; Singapore plants were found to be tetraploid. Amphineuron is not so clearly definable as Christella and needs more study from living plants. It is most diversified in Malesia, where some species form very large plants. Some species have quite free veins, a few have basal veins always anastomosing, and some have basal veins just meeting below the sinus or just failing to meet. Their unicellular glands are variable, some being elongate and resinous, often collapsing on drying, so that dried specimens are often difficult to identify with certainty. A opulentum has become naturalized in various parts of the New World.

As with so many widely-distributed ferns, C. dentata has had many names, each epithet transferred to various different genera by subsequent authors, so that the synonymy is very complex. A fairly full statement is given in my monograph of the genus Christella in 1976 (see synonymy).

Select Synonymy of Christella dentata:

Christella dentata (Forsskal) Brownsey \& Jermy, Brit. Fern. Gaz. 10 (1973) 338; Holttum, Kew Bull. 31 (1976) 314.

Basionym and its variants: Polypodim dentatum Forssk., Fl. Aegypt. Arab. (1773) 185. Dryopteris dentata C. Chr., Vid. selsk. Skr. VIII, 6 (1920) 24 (comment on type). Thelypteris dentata E. St. John, Amer. Fern Journ., 26 (1936) 44; A. R. Smith, Univ. Cal. Publ. Bot., 59 (1971) 57. Cyclosorus dentatus Ching, Bull. Fan Mem. Inst. Biol. Bot., 8 (1938) 206; Flora Europaea, 1 (1964) 14; Molesw. Allen Bol. R. Soc. Espag. Hist. Nat. (Biol.), 67 (1969) 75.

Synonyms and their variants:

1. Polypodium nymphale G. Forst., Fl. Ins. Austr. Prodr. (1786) 81. Aspidium nymphale Schkuhr, Kr. Gew., 1 (1806) 38, t. 34; Blume Enum. Pl. Jav. (1828) 157. Dryopteris nymphalis Copel., Bull. Bishop Mus., 59 (1929) 46. Thelypteris nymphalis Reed, Phytologia 17. (1968) 297. Christella nymphalis Pic. Ser., Webbia, 31 (1977) 252. (type from New Zealand).

2. Aspidium molle Sw. in Schrad. J. Bot. 1800, 2 (1801) 34, nom. nov for Polypodium molle Jacq. 1789, non Schreb. 1771. Nephrodium molle R. Br., Prodr. Fl. N. Holl. (1810) 149; Hook., Spec. Fil. 4 (1862) 68, p.p.; Bedd., Handb. Ferns Br. India (1883) 277, p.p. Dryopteris mollis Hieron., Hedwigia 46 (1907) 348. (type cult. Vienna). 
R.E. HOLTTUM

3. Aspidium violascens Link, Hort. Berol., 2 (1833) 115. Nephrodium violascens Fee, Gen. Fil. (1852) 305. (type cult. Berlin).

Comunicación presentada a la Reunión

Internacional de Pteridología(Algeciras,1980)

Dirección del autor: Royal Botanic Gardens, Kew Richmond Surrey, England. 